Research, part of a Special Feature on Understanding the Vulnerability and Sustainability of Urban Social-Ecological Systems in the Tropics: Perspectives from the City of San Juan

\title{
Trends in total rainfall, heavy rain events, and number of dry days in San Juan, Puerto Rico, 1955-2009
}

\author{
Pablo A. Méndez-Lázaro ${ }^{1}$, Alejandro Nieves-Santiango $^{2}$ and Julieanne Miranda-Bermúdez ${ }^{2}$
}

\begin{abstract}
Climate variability is a threat to water resources on a global scale and in tropical regions in particular. Rainfall events and patterns are associated worldwide with natural disasters like mudslides and landslides, meteorological phenomena like hurricanes, risks/hazards including severe storms and flooding, and health effects like vector-borne and waterborne diseases. Therefore, in the context of global change, research on rainfall patterns and their variations presents a challenge to the scientific community. The main objective of this research was to analyze recent trends in precipitation in the San Juan metropolitan area in Puerto Rico and their relationship with regional and global climate variations. The statistical trend analysis of precipitation was performed with the nonparametric Mann-Kendall test. All stations showed positive trends of increasing annual rainfall between 1955 and 2009. The winter months of January and February had an increase in monthly rainfall, although winter is normally a dry season on the island. Regarding dry days, we found an annual decreasing trend, also specifically in winter. In terms of numbers of severe rainfall events described as more than $78 \mathrm{~mm}$ in 24 hours, 63 episodes have occurred in the San Juan area in the last decade, specifically in the 2000-2009 time frame, with an average of 6 severe events per year. The majority of the episodes occurred in summer, more frequently in August and September. These results can be seen as a clear example of the complexity of spatial and temporal of rainfall distribution over a tropical city.
\end{abstract}

Key Words: climate variability; Puerto Rico; rainfall patterns; San Juan; trend analysis

\section{INTRODUCTION}

Climate change has been a topic of interest to many researchers with multiple areas of expertise. One of the most important necessities of research into climate change is to analyze and detect historical changes in the climatic system (Cannarozzo et al. 2006). Water availability is an important limiting factor for biological activities, and small variations in the amount, frequency, and intensity of water availability may have important consequences for the dynamics of human/natural systems (Ceballos-Barbancho et al. 2008). Changes in precipitation directly affect water resource management, agriculture, hydrology, natural ecosystems, and human health. For this reason it is important to investigate the changes in the spatial and temporal rainfall pattern to improve water management strategies (Cannarozzo et al. 2006).

Studies of yearly and seasonal precipitation on global and local scales reveal trends over many regions of the world (Brunetti et al. 2000, Jury 2009). Krishnakumar et al. (2009) observed a significant decrease in the southwest monsoon rainfall in India and an increase in the postmonsoon season. Ceballos-Barbancho et al. (2008) confirmed in Spain the general provisions of the Intergovernmental Panel on Climate Change, with a predominance of dry years over wet ones and a negative rainfall trend in the central sector of the country. In Botswana, Batisani and Yarnal (2009) identified a trend toward decreased rainfall throughout the nation, which is associated with decreases in the number of rainy days.

More related to the study area of this research, Neelin et al. (2006) observed that several data sets showed a significant summer drying trend in the Caribbean-Central-America region, a main region of intermodal agreement. More specifically in the
Caribbean, Laing (2004) studied the environments associated with three episodes of heavy precipitation and flash floods. These cases of heavy precipitation occurred during what is normally the dry season in the Caribbean.

Variations in total precipitation can be caused by a change in the frequency of precipitation events or in the intensity of precipitation per event, or a combination of both. Daily precipitation records must be analyzed to improve the understanding of how precipitation has acted as an indicator of climate variability over the last decades (Brunetti et al. 2000). This type of study has been done by Brunetti et al. (2000), Cannarozzo et al. (2006), and Xu et al. (2010). Changes in the dynamics and patterns of geophysical parameters may significantly affect different components of the hydrological cycle including runoff, floods, and droughts.

General circulation models provide a means of estimating climate change in the future by providing a time series of climatic variables. We believe our research was innovative because we studied the impact of climate change, or variability, on rainfall patterns during appropriately long periods of time using existing knowledge of the dynamics of these effects. We analyzed recent rainfall trends in the metropolitan area of San Juan, Puerto Rico, and their relationship with local climate variation from 1955 to 2009. In the context of climate change, heavy rainfall patterns and dry days were also analyzed.

\section{STUDY AREA}

The study area consisted of the metropolitan area of San Juan and the basin of the Río Piedras. This basin of $67.3 \mathrm{~km}^{2}$ is the main hydrologic unit in the municipality of San Juan, with a small

${ }^{1}$ Faculty of Biosocial Sciences and Graduate School of Public Health, and Department of Environmental Health, University of Puerto RicoMedical Sciences Campus, ${ }^{2}$ Graduate School of Public Health and Center for Public Health Preparedness, University of Puerto Rico-Medical Sciences Campus 
portion also including the municipalities of Guaynabo and Trujillo Alto. These three municipalities constitute the most urbanized basins in the island (Fig. 1).

Fig. 1. San Juan metropolitan area and National Oceanic and Atmospheric Administration (NOAA) weather stations.
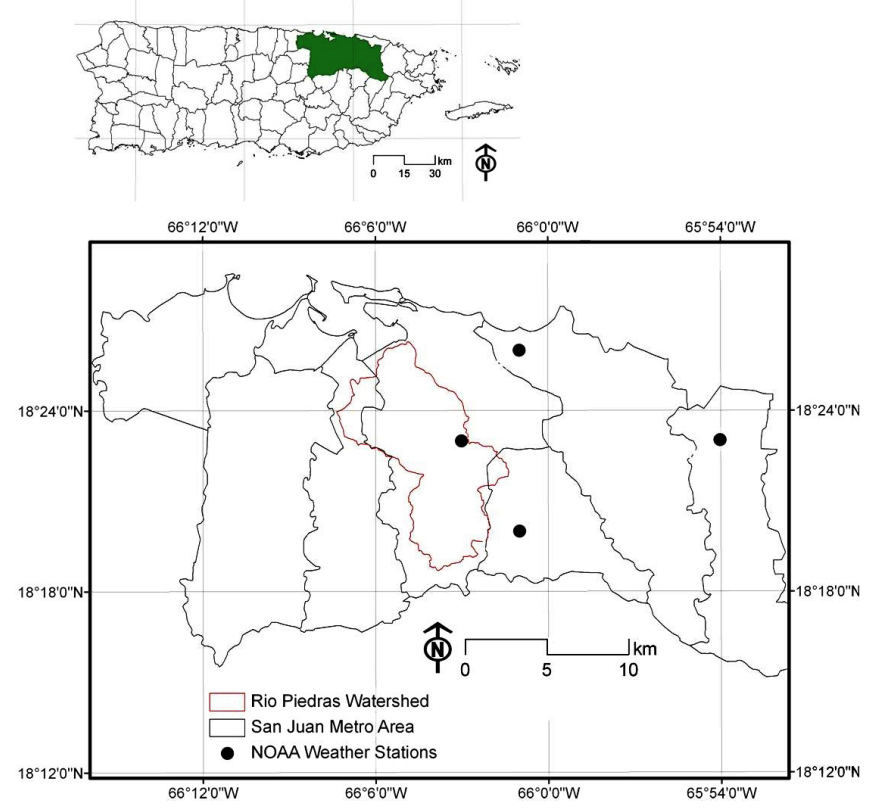

The metropolitan area of San Juan has a subtropical humid climate, very similar to that of other cities in Puerto Rico and in the Caribbean region, with an annual average rainfall of 1800 $\mathrm{mm}$. It has two seasons, a relatively dry season in the winter months with slight increases in rainfall in May and rainfall decreasing again in June and July; and a wet season in summer and autumn (Fig. 2).

\section{DATABASE AND METHODS}

Four meteorological stations were used in this research. The weather stations belong to the U.S. National Oceanic and Atmospheric Administration's Southeast Regional Climate Center. To maintain data quality, we selected weather stations that had more than 31 years of available daily data and for which the series was the most recent (Table 1). Stations were discarded if they had large information gaps and large quantities of missing values (more than 10\%); for example, those that were missing more than three years for each series and more than three months for each year were discarded (González Hidalgo et al. 2002). Rainfall trends and patterns can be compared with the results of previous studies in Puerto Rico (Méndez Lázaro and Martínez 2012, Méndez-Lázaro et al. 2012).

Rainfall indices (Table 2) were developed to categorize the available data into dry days (recorded rainfall $<1 \mathrm{~mm} / 24 \mathrm{~h}$; RR0) and wet days (recorded daily rainfall $\geq 1 \mathrm{~mm} / 24 \mathrm{~h}$; RR 1 ). We used a robust statistical method for trend analysis: the Mann-Kendall (MK) trend test (Yue et al. 2001, Kuo et al. 2011). This is a nonparametric test to detect trends in data (McCuen 2003). This test
Fig. 2. Average annual rainfall distribution in San Juan metropolitan area.

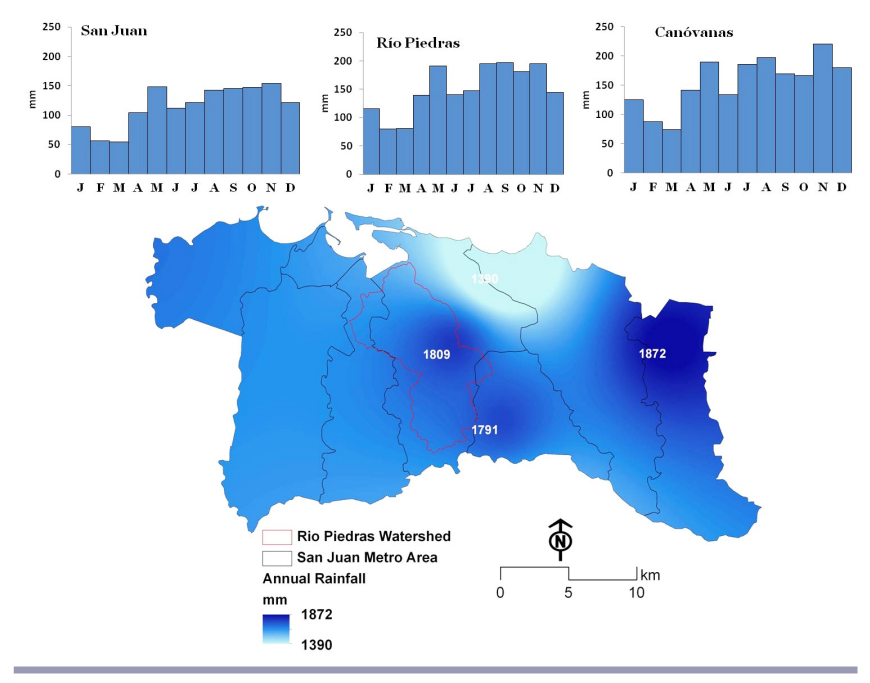

$$
S=\sum_{k=1}^{n-1} \sum_{j=k+1}^{n} \operatorname{sgn}\left(x_{j}-x_{k}\right)
$$

and

$$
\begin{array}{r}
\operatorname{sgn}\left(x_{j}-x_{k}\right)=+1 \text { if }\left(x_{j}-x_{k}\right)>0 \\
0 \text { if }\left(x_{j}-x_{k}\right)=0 \\
-1 \text { if }\left(x_{j}-x_{k}\right)<0
\end{array}
$$

has been used by different researchers for trend studies with hydroclimatic data (Yue et al. 2001, Hamed 2007, Luo et al. 2008, McBean and Mootie 2008). The MK test involves computing the $\mathrm{S}$ statistic, which is the difference between the numbers of pairwise differences that are positive minus the numbers that are negative. The MK test does not assume any particular distributional form and accommodates values below the detection limit by assigning them a common value (Allende and Mendoza 2007, Baggaley et al. 2009).

The variable $n$ indicates the number of observed data points in the series. Let the time series consist of $n$ data points, and $X_{\mathrm{k}}$ and $X_{\mathrm{j}}$ are two subsets of data where $k=1,2,3, \ldots, n-1$ and $j=k+1$, $\mathrm{i}+2, \mathrm{i}+3, \ldots, n$. Each data point $X_{\mathrm{k}}$ is used as a reference point and is compared with all the $X_{\mathrm{j}}$ data points (Allende and Mendoza 2007, McBean and Mootie 2008). The alternative hypothesis is that of either an upward trend or a downward trend.

A positive trend is detected when the most recent data tend to be superior to the earlier data. A negative trend is detected when the latest data tend to be inferior to the previous data. When S displays a highly positive value, it shows a positive trend. When $\mathrm{S}$ displays a highly negative value, it shows a negative trend.

For a series of data $n>10$, the $\mathrm{Z}$ statistic is used.

$$
Z_{0}=\frac{S-\operatorname{sigh}(s)}{\sqrt{V(S)}}
$$


Table 1. Weather stations within the San Juan metropolitan area.

\begin{tabular}{|c|c|c|c|c|c|}
\hline Stations & Period & Code & Elevation (ft) & Lat/Long. & $\begin{array}{c}\text { Missing Values } \\
\%\end{array}$ \\
\hline Río Piedras Exp. Station & $1955-2009$ & 668306 & 92 & $18^{\circ} 25 \mathrm{~N} 66^{\circ} 04 \mathrm{~W}$ & $5.7 \%$ \\
\hline San Juan LMM & $1955-2009$ & 668812 & 9 & $18^{\circ} 26 \mathrm{~N} 66^{\circ} 01 \mathrm{~W}$ & $0.2 \%$ \\
\hline Gurabo Substation & $1955-2009$ & 664276 & 160 & $18^{\circ} 15 \mathrm{~N} 66^{\circ} 00 \mathrm{~W}$ & $0.9 \%$ \\
\hline Canóvanas & $1955-2009$ & & 30 & $18^{\circ} 23 \mathrm{~N} 65^{\circ} 54 \mathrm{~W}$ & $1.7 \%$ \\
\hline $\begin{array}{l}\text { Toa Baja } 1 \text { SSW / Constancia } \\
\text { / Levittown }\end{array}$ & 1955-1994 & 669421 & 20 & $18^{\circ} 26 \mathrm{~N} 66^{\circ} 16 \mathrm{~W}$ & $4.6 \%$ \\
\hline Trujillo Alto & 1970-2009 & 669521 & 115 & $18^{\circ} 20 \mathrm{~N} 66^{\circ} 01 \mathrm{~W}$ & $12.0 \%$ \\
\hline Caguas 2 WNW / 1 WSN & 1970-1995 & 661309 & 260 & $18^{\circ} 14 \mathrm{~N} 66^{\circ} 03 \mathrm{~W}$ & $8.5 \%$ \\
\hline La Muda Caguas & 1971-1994 & 665123 & 290 & $18^{\circ} 19 \mathrm{~N} 66^{\circ} 06 \mathrm{~W}$ & $9.1 \%$ \\
\hline Cataño & 1955-1977 & 661845 & 20 & $18^{\circ} 25 \mathrm{~N} 66^{\circ} 07 \mathrm{~W}$ & $6.2 \%$ \\
\hline San Juan City & 1955-1977 & 668808 & 20 & $18^{\circ} 28 \mathrm{~N} 66^{\circ} 06 \mathrm{~W}$ & $5.6 \%$ \\
\hline
\end{tabular}

Bold: Stations that did not meet selection criteria.

Table 2. Rainfall index description. Source: ECA\&D Project Team 2012.

\begin{tabular}{lll}
\hline \hline Acronyms & \multicolumn{1}{c}{ Description } & Units \\
\hline RR & $\begin{array}{l}\text { Precipitation sum is defined as the } \\
\text { daily precipitation for 1 day over } \\
\text { the period of 24 hours. }\end{array}$ & $(\mathrm{mm})$ \\
WR1 & $\begin{array}{l}\text { Wet days are counted as the } \\
\text { number of days where (RR } \geq 1 \\
\text { mm. }\end{array}$ & (Freq.) \\
RR0 & $\begin{array}{l}\text { Dry days are counted as the } \\
\text { number of days where (RR }<1 \\
\text { mm). }\end{array}$ & (Freq.) \\
CDD & $\begin{array}{l}\text { Number of dry days (RR0) over } \\
\text { consecutive period of }(>3(\mathrm{x})<8 \\
\text { days) the time series. }\end{array}$ & (Freq.) \\
& &
\end{tabular}

In this statistical test, the null hypothesis $\left(\mathrm{H}_{0}\right)$ relies on the fact that there is no trend.

The variable $g$ represents the number of tied groups and $t_{\mathrm{j}}$ is the number of points in the $j_{\text {th }}$ group when $\mathrm{S}$ equals the total number of positive differences minus the total number of negative differences and $\mathrm{V}(\mathrm{S})$ is

$$
V(S)-\frac{1}{18}\left[n(n-1)(2 n+5)-\sum_{j-1}^{g} t_{j}\left(t_{j}-1\right)\left(2 t_{j}+5\right)\right]
$$

Note that $\operatorname{sign}(S)=1$ if $S>0$, sign $(S)=0$ if $S=0$, and $\operatorname{sign}(S)$ $=-1$ if $S<0$. If $z_{0}>z_{1}-\alpha$, then the null hypothesis of no trend is rejected.

MK statistical significance was also analyzed with the $P$ value. If $\mathrm{P}<\alpha$, then we rejected the null hypothesis of no trend. This value does not quantify the probability that a certain hypothesis is accurate in light of the data. It rather quantifies the probability of obtaining certain data, assuming that a certain hypothesis is accurate, as has been noted.
MK statistical analysis is very robust and highly recommended by different researchers, as well as various environmental administrations, for studies of trends with hydro-climatic data (Yue et al. 2001, Luo et al. 2008). The MK test can indicate whether there is any negative or positive trend in rainfall (Allende and Mendoza 2007). Were also analyzed extreme weather events, i.e., rainfall of more than $78 \mathrm{~mm}$ in 24 hours, and dry days.

\section{RESULTS AND DISCUSSION}

We observed changes in annual and monthly rainfall in the San Juan metropolitan area over the last decades of the 20th century. All stations showed great oscillation and variability compared with normal values, making it possible to identify wet and dry periods (Fig. 3). Positive trends between 1955 and 2009 can be established (Table 3). Similarly, changes in the natural behavior of the hydrological cycle have been identified. In December monthly total rainfall decreased at all analyzed stations, whereas in the winter months of January and February, total precipitation increased (Table 3 ). These findings are relevant when considering seasonal changes and trends (Table 4). The summer months of June, July, and August showed regressive trends at all weather stations, even though only the trend at Canóvanas reached statistical significance. In contrast, the fall months of September, October, and November had positive trends at all four weather stations (Fig. 4).

These monthly trends can be also confirmed in part by the analysis of dry days (RR0). Between 1955 and 2009 the San Juan metropolitan area used to have an average of 136 dry days per year. Table 5 shows that dry days are decreasing at three out of four stations annually; these patterns can be confirmed by combining data from all the weather stations (Fig. 5). Moreover, with dry spell analysis (consecutive dry days, CDDs), two out of four weather stations had regressive trends (San Juan LLM, Río Piedras Experiment Station), while Canóvanas showed positive values (Table 6). Dry days and the dry season normally occurred in winter; nevertheless, Río Piedras Experiment Station showed a negative trend for both RR0 and CDDs. 
Table 3. Annual and monthly rainfall trend analysis. Mann-Kendall (S).

\begin{tabular}{|c|c|c|c|c|c|c|c|c|c|c|c|c|c|}
\hline $\begin{array}{l}\text { NOAA/ } \\
\text { STATIONS }\end{array}$ & JAN & FEB & MAR & APR & MAY & JUN & JUL & AUG & SEP & OCT & NOV & DEC & Annual \\
\hline Canóvanas & 395 & 123 & -30 & 132 & -232 & -153 & -49 & -121 & 167 & 187 & 197 & -2 & 145 \\
\hline Gurabo & 160 & 169 & 246 & 19 & -83 & -125 & 131 & -127 & 77 & 243 & 116 & -70 & 207 \\
\hline Río Piedras & 196 & -67 & 220 & 136 & 3 & -45 & -245 & -17 & 203 & -37 & 204 & -314 & 111 \\
\hline San Juan & 113 & 86 & -251 & 189 & -195 & -67 & 69 & -146 & 29 & -32 & 274 & -81 & 3 \\
\hline
\end{tabular}

Bold indicates that the computed $\mathrm{Z}$ value was above the significance level $(|\mathrm{Z}|>1.645)$; therefore, one should reject the null hypothesis (there is no trend in the series) and accept the alternative hypothesis.

Fig. 3. Rainfall variability 1955-2009 compared with 1981-2010 climatology (normal values).
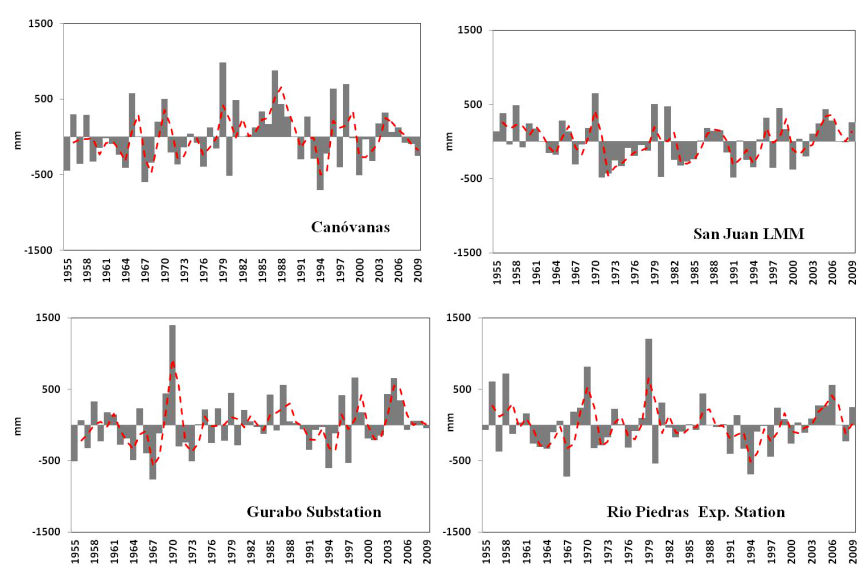

Fig. 4. Fall histogram with trend lines.

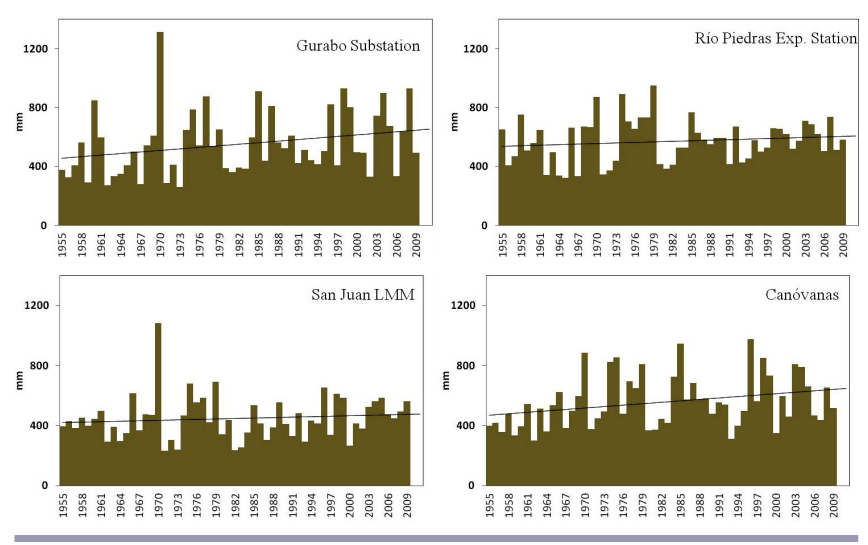

A total of 63 severe rainfall events, described as more than $78 \mathrm{~mm}$ in 24 hours, occurred over the San Juan metropolitan area between 2000 and 2009, with an average of 6 severe events per year; 4 of these events were recorded at more than one station. Río Piedras Experiment Station (26 severe events) and Gurabo Substation (16 severe events) are the stations where more episodes were registered. The majority of the episodes occurred in summer
Fig. 5. Dry days trends in San Juan metropolitan area. DJF (December-January-February), JJA (June-July-August)

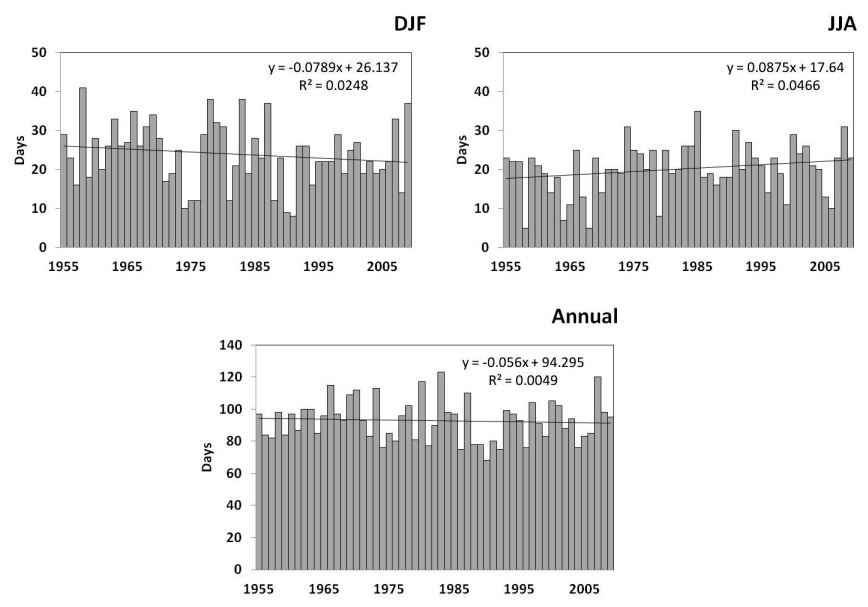

Table 4. Seasonal trends. Mann-Kendall (S).

\begin{tabular}{lcccc}
\hline \hline & $\begin{array}{c}\text { Winter } \\
\text { (DJF) }\end{array}$ & $\begin{array}{c}\text { Summer } \\
(\text { JJA })\end{array}$ & $\begin{array}{c}\text { Fall } \\
\text { (SON) }\end{array}$ & $\begin{array}{c}\text { Spring } \\
\text { (MAM) }\end{array}$ \\
\hline San Juan LLA & 22 & -87 & 180 & -59 \\
Río Piedras Exp. & -99 & -169 & 175 & 106 \\
$\begin{array}{l}\text { Station } \\
\text { Gurabo }\end{array}$ & -75 & 103 & $\mathbf{3 2 0}$ & 89 \\
$\begin{array}{l}\text { Substation } \\
\text { Canóvanas }\end{array}$ & -83 & $\mathbf{- 8 9 5}$ & $\mathbf{3 0 0}$ & -77 \\
\hline
\end{tabular}

Bold indicates that the computed $\mathrm{Z}$ value was above the significance level $(|Z|>1.645)$; therefore, one should reject the null hypothesis (there is no trend in the series) and accept the alternative hypothesis. DJF $=$ December-January-February

$\mathrm{JJA}=$ June-July-August

SON = September-October-November

MAM = March-April-May 
( $n=24)$, the beginning of the hurricane season in the North Atlantic, but were more frequent in August and September. These episodes occasionally occurred in winter $(n=4)$, all of them in the Río Piedras Experiment Station. In general terms, severe events were more frequent in summer in Río Piedras, although more intense in spring, with $139 \mathrm{~mm}$ in 24 hours.

Table 5. Mann-Kendall trend analysis for dry days. JJA = JuneJuly-August; DJF = December-January-February.

\begin{tabular}{lccc}
\hline \hline Station & $\begin{array}{c}\text { Annual } \\
(\mathrm{p} \text {-value) }\end{array}$ & $\begin{array}{c}\text { JJA } \\
(\mathrm{p} \text {-value })\end{array}$ & $\begin{array}{c}\text { DJF } \\
(\mathrm{p} \text {-value) }\end{array}$ \\
\hline Río Piedras & $\mathbf{- 4 . 6 8 ( \mathbf { 0 . 0 0 1 } )}$ & $\mathbf{- 2 . 6 1 ( \mathbf { 0 . 0 0 4 5 ) }}$ & $\mathbf{- 4 . 6 7 ( \mathbf { 0 . 0 0 1 ) }}$ \\
San Juan & $\mathbf{- 1 0 . 7 9 ( 0 . 0 0 1 )}$ & $-0.85(0.1977)$ & $-1.47(0.0708)$ \\
Gurabo & $\mathbf{- 4 . 9 1 ( \mathbf { 0 . 0 0 1 ) }}$ & $-0.75(0.2266)$ & $\mathbf{- 3 . 0 5 ( 0 . 0 0 1 1 )}$ \\
Canóvanas & $1.11(0.1335)$ & $\mathbf{2 . 8 7 ( \mathbf { 0 . 0 0 2 1 } )}$ & $-0.40(0.3446)$ \\
Metropolitan & $-0.60(0.2743)$ & $1.31(0.0951)$ & $-1.26(0.1038)$ \\
Area & & & \\
\hline
\end{tabular}

Bold indicates that the computed $\mathrm{Z}$ value was above the significance level $(|Z|>1.645)$; therefore, one should reject the null hypothesis (there is no trend in the series) and accept the alternative hypothesis.

Table 6. Mann Kendall trend analysis for consecutive periods of dry days ( $>3$ days $<8$ days).

\begin{tabular}{lccc}
\hline \hline Station & $\begin{array}{c}\text { Annual }(\mathrm{p}- \\
\text { value })\end{array}$ & JJA (p-value) & DJF (p-value) \\
\hline Río Piedras & $\mathbf{- 3 . 7 8 ( \mathbf { 0 . 0 0 0 1 } )}$ & $\mathbf{- 2 . 5 0 ( \mathbf { 0 . 0 0 6 2 } )}$ & $\mathbf{- 2 . 9 9 ( \mathbf { 0 . 0 0 1 4 } )}$ \\
San Juan & $\mathbf{- 1 . 6 7 ( 0 . 0 4 7 5 )}$ & $0.12(0.4522)$ & $\mathbf{- 1 . 7 9 ( \mathbf { 0 . 0 3 6 7 ) }}$ \\
Gurabo & $-0.12(0.4522)$ & $0.46(0.3228)$ & $-1.34(0.0901)$ \\
Canóvanas & $\mathbf{1 . 9 5 ( 0 . 0 2 5 6 )}$ & $\mathbf{2 . 7 5 ( 0 . 0 0 3 )}$ & $1.07(0.1423)$ \\
Metropolitan & $-0.54(0.2946)$ & $-0.75(0.2266)$ & $-0.86(0.1949)$ \\
Area & & &
\end{tabular}

Area

Bold indicates that the computed $\mathrm{Z}$ value was above the significance level $(|Z|>1.645)$; therefore, one should reject the null hypothesis (there is no trend in the series) and accept the alternative hypothesis.

In the years 2003 and 2004, there were eight and nine registered severe rainfall events, respectively; in 2007 and 2008, there were three and four episodes, respectively. The most intense rainfall event, $207 \mathrm{~mm}$ in 24 hours, occurred in spring (24 April 2006) and was only registered in the Río Piedras station. This can be seen as an example of the remarkable complexity of rainfall spatial distribution over a tropical city such as San Juan. Clear patterns and trends of severe rainfall events in the San Juan metropolitan area cannot be established from 1955 to 2009 (Table 7).

These episodes might have a direct effect on environmental public health. As discussed by Quintero et al. (2010), high-intensity rain diminished the concentration of fungal spores in the atmosphere in San Juan, Puerto Rico. Fungal aerosols have been correlated in different studies with respiratory problems (Bolaños-Rosero et al. 2013). Quintero et al. also noted that the concentrations of fungal spore aerosols increased during and after the rain events. Because the prevalence of asthma in Puerto Rico is approximately
$16.5 \%$ and in some areas is almost $46 \%$ in elementary-school children (Loyo-Berríos et al. 2006), our research could be very useful for public health preparedness once the rainfall trends and patterns are well characterized.

Table 7. Mann-Kendall trend analysis for heavy rainfall.

\begin{tabular}{lccc}
\hline \hline Station & $\begin{array}{c}\text { Annual (p- } \\
\text { value) }\end{array}$ & JJA (p-value) & DJF (p-value) \\
\hline Río Piedras & $0.61(0.2709)$ & $0.60(0.2743)$ & $0.56(0.2877)$ \\
San Juan & $1.17(0.121)$ & $-0.16(0.4364)$ & $-0.28(0.3897)$ \\
Gurabo & $1.02(0.1539)$ & $-0.05(0.4801)$ & $-0.59(0.2776)$ \\
Canóvanas & $-0.62(0.2676)$ & $0.61(0.2709)$ & $-0.40(0.3446)$ \\
Metropolitan & $1.05(0.1469)$ & $0.90(0.1841)$ & $0.19(0.4247)$ \\
Area & & & \\
\hline
\end{tabular}

These changes in rainfall patterns and events are similar to those reported by Peterson et al. (2002) for the Caribbean as a whole. The maximum number of CDDs is decreasing and the number of heavy rainfall events is increasing in the Caribbean (Peterson et al. 2002). Similar patterns for rainfall have also been registered in Cuba (Centella et al. 1999). In both Puerto Rico and Cuba, annual precipitation is increasing in the winter months and decreasing in the summer (Méndez Lázaro and Martínez 2012). It may be that these results to some extent reflect the complexity of precipitation patterns in tropical areas including Puerto Rico. All these detected changes might be influenced by the El Niño southern oscillation and the North Atlantic oscillation (Giannini et al. 2001, Jury 2008). A warm El Niño southern oscillation and a positive North Atlantic oscillation should have a negative impact on summer rainfall in the Caribbean. Figure 3 shows annual variability, anomalies, and oscillations in each of the four weather stations.

There is global concern that climate change will make certain environments suitable for vector-borne diseases, worsening their already significant global burden and potentially reintroducing some diseases into areas where they had been previously eradicated (Portier et al. 2010, Mendez-Lazaro 2012). The temporal and spatial changes in temperature, precipitation, and humidity that are expected to occur under different climate change scenarios will affect the biology and ecology of vectors and intermediate hosts, and consequently the risk of disease transmission (Githeko et al. 2000). In general, insects are exceedingly sensitive to temperature and rainfall regimens and patterns, and all the tropical and temperate species frequently show high variation in seasonal abundance (Brunkard et al. 2008).

According to Li et al. (1985), a quantitative association between rainfall and the number of dengue cases was found during the first wet period in Malaysia, showing a lag time between the onset of heavy rain and dengue outbreak of about two to three months; a $120 \%$ increase in the number of dengue cases was observed when the monthly rainfall was $300 \mathrm{~mm}$ or more. Dengue in Puerto Rico is seasonal, with three periods: postepidemic from December to May, with low temperature, little precipitation, and few mosquitoes; pre-epidemic from June to August, with high temperature and abundant precipitation and mosquitoes; and epidemic from September to November, with environmental 
conditions similar to those in the pre-epidemic period (Barrera 2010). Pre-epidemic and epidemic conditions in Puerto Rico occur in the summer and fall, the same seasons that heavy rainfall events are more frequent. Even though Jury (2008) mentioned that seasonal fluctuations of dengue were driven by rainfall increases from May to November, he concluded that dengue cases were positively related to temperature and weakly associated with local rainfall. New approaches can focus on analyzing how regional and bigger-scale atmospheric phenomena will control and influence the Caribbean region in the next decade (Malmgren et al. 1998, Giannini et al. 2001, Jury et al. 2007).

\section{CONCLUSION}

In this paper, we present the most recent and updated research analyzing rainfall trends in Puerto Rico in a climate change context, using registered data from 1955 through 2009. Based on the results, rainfall trends and variability in San Juan, Puerto Rico, appear to be very complex. We observed that the total annual rainfall increased slightly and observed regressive trends more frequently in summer than in winter. These results were confirmed by dry day trend analysis. According to this analysis, dry days decreased in the San Juan metropolitan area between 1955 and 2009 and were more common in the winter months. Heavy rains were more common in summer and fall in accordance with the hurricane season, whereas the most intense rainfall episodes tended to occur in spring.

Taking under consideration the complexity of urban areas and the Caribbean climate conditions, further research should involve characterizing additional rainfall indices, such as defining extreme weather events or expanding the study area. In addition, analyzing trends in previous years in Puerto Rico could enable better understanding of past rainfall conditions. The hydroclimatic information presented here supports further climate change risk assessment and vulnerability adaptation planning in Puerto Rico. Understanding the interrelations between climate and environmental threats, and the effects that climate variability has on both of them, will help define possible effects on life, ecosystems, and public health. Adaptation strategies and measures, i.e., policies, as well as public health interventions then can be applied.

Responses to this article can be read online at: http://www.ecologyandsociety.org/issues/responses. $\mathrm{php/6464}$

\section{Acknowledgments:}

This research paper was made possible by the Urban Long Term Research Area program, thanks to funding provided by the National Science Foundation and U.S. Forest Service. We also are grateful to the students from the Graduate School of Public Health, University of Puerto Rico-Medical Sciences Campus, who collaborated in this research with data entry and data management: Nichole Ortiz-Cruz, Shirley Delgado-Rivera, and Paola PrietoPulido. Thank you all for their generous contribution to this project.

\section{LITERATURE CITED}

Allende, T. C., and M. E. Mendoza. 2007. Análisis hidrometeorológico de las estaciones del Lago de Cuitzeo. Investigaciones Geográficas 63:56-76.

Baggaley, N. J., S. J. Langan, M. N. Futter, J. M. Potts, and S. M. Dunn. 2009. Long-term trends in hydro-climatology of a major Scottish mountain river. Science of the Total Environment 407 (16):4633-4641. http://dx.doi.org/10.1016/j.scitotenv.2009.04.015

Barrera, R. 2010. Dinámica del dengue y Aedes aegypti en Puerto Rico. Revista Biomédica 21:179-195.

Batisani, N., and B. Yarnal. 2009. Rainfall variability and trends in semi-arid Botswana: implications for climate change adaptation policy. Applied Geography 30(4):483-489. http://dx. doi.org/10.1016/j.apgeog.2009.10.007

Bolaños-Rosero, B., D. Betancourt, T. Dean, and S. Vesper. 2013. Pilot study of mold populations inside and outside of Puerto Rican residences. Aerobiologia 29(4):537-543. http://dx.doi. org/10.1007/s10453-013-9301-7

Brunetti, M., L. Buffoni, M. Maugeri, and T. Nanni. 2000. Precipitation intensity trends in northern Italy. International Journal of Climatology 20(9):1017-1031. http://dx.doi. org/10.1002/1097-0088(200007)20:9<1017::aid-joc515>3.0.CO;2$\underline{S}$

Brunkard, J. M., E. Cifuentes, and S. J. Rothenberg. 2008. Assessing the roles of temperature, precipitation, and ENSO in dengue re-emergence on the Texas-Mexico border region. Salud Pública de México 50(3):227-234. http://dx.doi.org/10.1590/ $\underline{\text { S0036-36342008000300006 }}$

Cannarozzo, M., L. V. Noto, and F. Viola. 2006. Spatial distribution of rainfall trends in Sicily (1921-2000). Physics and Chemistry of the Earth, Parts A/B/C 31(18):1201-1211. http://dx. doi.org/10.1016/j.pce.2006.03.022

Ceballos-Barbancho, A., E. Morán-Tejeda, M. A. LuengoUgidos, and J. M. Llorente-Pinto. 2008. Water resources and environmental change in a Mediterranean environment: the south-west sector of the Duero river basin (Spain). Journal of Hydrology 351(2):126-138. http://dx.doi.org/10.1016/j.jhydrol.2007.12.004

Centella, A., T. Gutiérrez, M. Limia, and R. Rivero Jaspe. 1999. Climate change scenarios for impact assessment in Cuba. Climate Research12(2-3):223-230. http://dx.doi.org/10.3354/cr012223

European Climate Assessment \& Dataset (ECA\&D) Project Team. 2012. Algorithm Theoretical Basis Document (ATBD). Version 10.6. Project number EPJ029135. Royal Netherlands Meteorological Institute KNMI, De Bilt, Utrecht, The Netherlands.

Giannini, A., M. A. Cane, and Y. Kushnir. 2001. Interdecadal change in the ENSO teleconnection to the Caribbean region and the North Atlantic oscillation. Journal of Climate 14:2867-2879. http://journals.ametsoc.org/doi/abs/10.1175/1520-0442\%282001\% 29014\%3C2867\%3AICITET \%3E2.0.CO \%3B2

Githeko, A. K., S. W. Lindsay, U. E. Confalonieri, and J. A. Patz. 2000. Climate change and vector-borne diseases: a regional analysis. Bulletin of the World Health Organization 78 (9):1136-1147. 
González Hidalgo J. C., M. De LuÍs, P. Štepánek, J. Raventós, and J. M. Cuadrat. 2002. Reconstrucción estabilidad y Proceso de homogeneizado de series de precipitación en ambientes de elevada variabilidad pluvial. VII Reunión Nacional de Climatología. Grupo de Clima de la Asociación de Geógrafos Españoles, Albarracín, Spain.

Hamed, K. H. 2007. Trend detection in hydrologic data: the Mann-Kendall trend test under the scaling hypothesis. Journal of Hydrology 349(3-4):350-363. http://dx.doi.org/10.1016/j. jhydrol.2007.11.009

Jury, M., B. A. Malmgrem, and A. Winter. 2007. Subregional precipitation climate of the Caribbean and relationships with ENSO and NAO. Journal of Geophysical Research: Atmospheres 112(D16107). http://dx.doi.org/10.1029/2006JD007541

Jury, M. R. 2008. Climate influence on dengue epidemics in Puerto Rico. International Journal of Environmental Health Research 18(5):323-334. http://dx.doi.org/ 10.1080/09603120701849836

Jury, M. R. 2009. A quasi-decadal cycle in Caribbean climate. Journal of Geophysical Research: Atmospheres 114(D13102). http://dx.doi.org/10.1029/2009JD011741

Krishnakumar, K. N., G. S. L. H. V. Prasada Rao, and C. S. Gopakumar. 2009. Rainfall trends in twentieth century over Kerala, India. Atmospheric Environment 43(11):1940-1944. http:// dx.doi.org/10.1016/j.atmosenv.2008.12.053

Kuo, Y.-M., H.-J. Chu, T.-Y. Pan, and H.-L. Yu. 2011. Investigating common trends of annual maximum rainfalls during heavy rainfall events in southern Taiwan. Journal of Hydrology 409(3-4):749-758. http://dx.doi.org/10.1016/j. jhydrol.2011.09.015

Laing, A. G. 2004. Cases of heavy precipitation and flash floods in the Caribbean during El Niño winters. Journal of Hydrometeorology 5(4):577-594. http://dx.doi.org/10.1175/1525-7541 (2004)005<0577:cohpaf>2.0.CO:2

Li, C. F., T. W. Lim, L. L. Hann, and R. Fang. 1985. Rainfall, abundance of Aedes aegypti and dengue infection in Selangor, Malaysia. Southeast Asian Journal of Tropical Medicine and Public Health 16(4):560-568.

Loyo-Berríos, N. I., J. C. Orengo, and R. A. Serrano-Rodríguez. 2006. Childhood asthma prevalence in northern Puerto Rico, the Rio Grande, and Loíza experience. Journal of Asthma 43 (6):619-624.

Luo, Y., S. Liu, S. Fu, J. Liu, G. Wang, and G. Zhou. 2008. Trends of precipitation in Beijiang River Basin, Guangdong Province, China. Hydrological Processes 22(13):2377-2386. http://dx.doi. org/10.1002/hyp.6801

Malmgren, B. A., A. Winter, and D. Chen. 1998. El Niñosouthern oscillation and North Atlantic oscillation control of climate in Puerto Rico. Journal of Climate 11(10):2713-2717. http://dx.doi.org/10.1175/1520-0442(1998)011<2713:ENOSOA >2.0. $\mathrm{CO} ; 2$

McBean, E., and H. Mootie. 2008. Assessment of impact of climate change on water resources: a long term analysis of the Great Lakes of North America. Hydrology and Earth System Sciences 12:239-255. http://dx.doi.org/10.5194/hess-12-239-2008
McCuen, R. H. 2003. Modeling hydrologic change: statistical methods. Lewis, Boca Raton, Florida, USA.

Mendez-Lazaro, P. 2012. Potential impacts of climate change and variability on public health. Journal of Geology \& Geosciences 1: e104. http://dx.doi.org/10.4172/2329-6755.1000e104

Méndez Lázaro, P., and J. Martínez. 2012. Tendencias hidroclimáticas y cambios en el paisaje de Puerto Rico. Análisis hidroclimático. Editorial Académica Española, Saarbrücken, Alemania, Germany. ISBN 978-3-659-05902-5.

Méndez-Lázaro, P., A. Nieves-Santiago, S. Delgado-Rivera, P. Prieto-Pulido, and J. Miranda-Bermúdez. 2012. Effects of climate change in rainfall patterns in San Juan, Puerto Rico: last decades of the 20th century and beginning of the 21 st century [translated from the Spanish]. Pages 1244-1250 in J. Tapia, editor. Libro de trabajos en extenso primer congreso Latinoamericano de ecología urbana: desafios y escenarios de desarrollo para las ciudades Latinoamericanas. First edition. Universidad Nacional de General Sarmiento Ecología Urbana, Buenos Aires, Argentina. ISBN 978-987-28177-1-8.

Neelin, J. D., M. Münnich, H. Su, J. E. Meyerson, and C. E. Holloway. 2006. Tropical drying trends in global warming models and observations. Proceedings of the National Academy of Science of the United State of America 103(16):6110-6115. http://dx.doi. org/10.1073/pnas.0601798103

Peterson, T. C., M. A. Taylor, R. Demeritte, D. L. Duncombe, S. Burton, F. Thompson, A. Porter, M. Mercedes, E. Villegas, R. S. Fils, A. K. Tank, A. Martis, R. Warner, A. Joyette, W. Mills, L. Alexander, and B. Gleason. 2002. Recent changes in climate extremes in the Caribbean region. Journal of Geophysical Research 107(D21):4601. http://dx.doi.org/10.1029/2002JD002251

Portier, C. J., K. Thigpen-Tart, S.R. Carter, C. H. Dilworth, A. E. Grambsch, J. Gohlke, J. Hess, S. N. Howard, G. Luber, J. T. Lutz, T. Maslak, N. Maslak, M. Radtke, J. P. Rosenthal, T. Rowles, P. A. Sandifer, J. Scheraga, P. J. Schramm, D. Strickman, J. M. Trtanj, and P.-Y. Whung. 2010. A human health perspective on climate change: a report outlining the research needs on the human health effects of climate change. Environmental Health Perspectives and the National Institute of Environmental Health Sciences, Research Triangle Park, North Carolina, USA.

Quintero, E., F. Rivera-Mariani, and B. Bolaños-Rosero. 2010. Analysis of environmental factors and their effects on fungal spores in the atmosphere of a tropical urban area (San Juan, Puerto Rico). Aerobiologia 26(2):113-124. http://dx.doi. org/10.1007/s10453-009-9148-0

Xu, Z., Z. Liu, G. Fu, and Y. Chen. 2010. Trends of major hydroclimatic variables in the Tarim River basin during the past 50 years. Journal of Arid Environments 74(2):256-267. http://dx. doi.org/10.1016/j.jaridenv.2009.08.014

Yue, S., P. Pilon, and G. Cavadias. 2001. Power of the MannKendall and Spearman's rho tests for detecting monotonic trends in hydrological series. Journal of Hydrology 259(1-4):254-271. http://dx.doi.org/10.1016/S0022-1694(01)00594-7 